\title{
DIVERGENCIA VAGY KONVERGENCIA - AZ ÁTMENET GAZDASÁGI TÉRFOLYAMATAINAK MÉRLEGE FÖLDRAJZOS SZEMMEL ${ }^{1}$
}

\author{
(Convergence or Diverence: the Spatial Processes of Transition \\ from Point of View of a Geographer)
}

\author{
NAGY GÁBOR
}

Kulcsszavak:

területi egyenlö́tlenségek Human Development Index centrum-periféria viszonyrendszer térségek

A tanulmány arra keresi a választ, hogy a magyar területi folyamatok mérlegét az átmenet idöszakában hogy lehet megvonni. Elméleti hattérként néhány, a területi egyenlötlenségek alakulását magyarázó modellt alkalmaztunk, melyböl kiinduló hipotézisként a vizsgált idöszakra vonatkozóan a területi különbségek folyamatos, tartós növekedését jeleztük elöre. A vizsgálat a gazdaság oldaláról az egy före esö GDP PPP. ben, az EU 15-ökhöz viszonyított értékét hasznalta, míg társadalmi oldalról a kisszámú hazai elözményre támaszkodva kisérlet történt a HDI (Human Development Index) megyei szintũ értékeinek kiszámitására. A két komplex index (a HDI önmagában 14 tényezöt tömörít) azonos folyamatot jelez, a terïleti különbségek folyamatosan növekednek, băr a növekedés üteme az ezredfordulót követōen számottevöen lassult. Világosan elválik egymástól a nyertes (felzárkózó - gazdasági értelemben) és vesztes (stagnáló-leszakadó) megyék csoportja, s a két kategória közötti szakadék szélesedik, csökkentve az átjárhatóság esélyét.

\section{Az egyenlötlen területi fejlödés modelljei}

A területi polarizációt a gazdasági vizsgálatok homlokterébe emelö vizsgálatok és modellek az 1950-es évektől kezdődỏen kerültek a regionális kutatások fő irányvonalába. Gunnar Myrdal (1957) nevéhez köthető az irányzat, mely a régiók közötti induláskor meglévő egyensúlytalanságokból a kumulatív hatásokon, ok-okozati láncokon keresztül, a spread és backwash effektek tartós hatása révén a teriuleti egyenlötlenségek fennmaradását, a különbségek növekedését vallja. Ebbe a csoportba sorolható az ún. „új gazdaságföldrajz” atyja Paul Krugman (1991) is. Elmélete továbblépés Myrdalhoz képest, mert csekély induló különbségek mellett is magyarázni volt képes a területi egyenlőtlenségek megjelenését és megerősödését, sajátos regionális gazdasági karakter kifejlődését. Modelljében az agglomerációs gazdaság szerepe válik kulcsfontosságúvá, kezelni tudja az állami gazdaságpolitika hatását, de korlátja a technológiai externáliák elvetése, az innovációk elhanyagolása, a gazdasági növekedés folyamatának kidolgozatlansága.

Az előző irányzattal szemben a kutatók másik csoportja (Rostow 1960; Friedmann 1973; Richardson 1980) azt vallja, hogy a kapitalista termelési modell megjelenésével létrejött markáns regionális különbségek a tömeges termelés, a jólét általánossá válásával párhuzamosan oldódnak, s egyéni karakterü, a nemzeti gazdaságokba 
sokoldalúan beágyazott, egymáshoz hasonló fejlettségi szintủ régiók fognak kialakulni. A modellek lényege a spread effektek folyamatos jelenléte, melyek elöbb eröteljes gazdasági agglomerációk kialakulását segítik, majd később a területi kohézió és kiegyenlítés megteremtésében játszanak döntỏ szerepet.

Míg a fenti vélemények szerint a területi kiegyenlítődés a piaci erök spontán mozgásával megy végbe, addig a növekedési pólus elméletet valló gazdasági szakértők (Perroux 1955; Paelinck 1965; Pottier 1963; Boudeville 1966; Lasuén 1969) egyöntetüen az aktiv állami politika mellett voksolnak. Még a gazdasági értelemben elmaradott térségek esetében is esélyt látnak ágazati növekedési pólusok létrehozására, s a regionális multiplikátor hatásokon keresztuil a tágabb térség fejlődésének serkentésére. Igaz, Lasuén (1973) a fejlődỏ országok példáit elemezve rámutat a gyökértelen növekedési pólusnak a duális gazdasági struktúra kialakulásában játszott szerepére, a hoszszú távon rögzülő aránytalan térstruktúrára. A növekedési pólus elméletet kritizáló szakemberek azonban nem ezt, hanem a pólus és környezete közötti fejlödési kapcsolat erősségét, a kívülröl beplántált fejlődési mag tényleges hatásrendszerét vitatták. Az elmélet gyenge pontjainak feltárása egyik irányban az innováció-orientált, másik oldalon az endogén fejlődés elméletének kidolgozásához adott ösztönzést.

Az innováció-orientált iskola Schumpeter (1980) gondolataira építkezik, de annál tovább lépve az innovációk rendszerszemléletủ megközelítésével (Edquist 1997), a nemzeti innovációs rendszerek evolucionista felfogásával (Nelson 1982), illetve az interaktív tanulási folyamat lehetőségével és korlátaival (Lundvall 1992) foglalkozik. Számunkra a neo-schumpeteriánus iskola munkássága annyiban fontos, hogy felismerik a globális innovációs rendszerrel párhuzamosan létezö regionális innovációs rendszerek meglétét, melyből le tudják vezetni a régiók szintjén megjelenö földrajzi specializációt.

A belsö eröforrásokra építkezö fejlödési modellek a hetvenes évektöl a kilencvenes évekig jelentós fejlödésen mentek keresztül. Míg a korai elméleti írások szinte automatikus fejlődést és felzárkózást reméltek a belső erőforrások fokozott kiaknázásától, azok újszerủ kombinációkban való hasznosításától, addig az elmúlt évtizedet a technológiai tudás újszerủ felfogása, a neoklasszikus elméletekkel való határozott szakítás jellemzi. Romer (1994) értelmezésében a tudás (beleértve a rejtett tudáselemeket is) térben egyenlőtlenül oszlik meg, a tudástranszfer lehetósége térben korlátozott, és meghatározó a személyes tapasztalatcsere. A nem tökéletes versenyben a térbeli egyenlötlenségek megjelenése, tartós fennmaradása törvényszerü, bár a bázisinnovációk változása kapcsán egyes helyek, térségek - éppen a rejtett tudáselemek gyors aktivizálása révén - hosszabb távon is sikeresek lehetnek, míg más térségek az új gazdasági paradigmában elveszíthetik meglévỏ - hosszútávúnak tekintett - versenyelönyeiket.

A területi különbségek világgazdasági szinten értelmezett rendszerét a centrumperiféria modellek kísérlik meg bemutatni. Míg Wallerstein (1974) modellje a modern világgazdasági rendszer kialakulásának folyamatát absztrahálva duális modellben írta le a vizsgált folyamatokat, addig a területi kutatások a nemzetgazdasági léptékben megjelenö (Friedmann 1966), a települési szinten jelentkező (Haggett 1983), vagy éppen az áramlások keltette függőség modellezésében (Dicken 1992) alkottak 
maradandót. Utóbbi újszerü megközelítését adja a területi különbségek tartóssá válásának, miközben nem zárja ki a koncentrációs és dekoncentrációs (decentralizációs) folyamatok párhuzamos megjelenését. E megközelítésben a regionális hálózatok szerepe a komplex térszerkezet kialakításában, a földrajzi differenciálódásban kulcsfontosságú. Másik meghatározó elemmé a városrégiók, a klasszikus „,core-térségek” válnak.

A kilencvenes évek globalizációs elméletei is kapaszkodót nyújthatnak a Magyarországon zajló folyamatok jobb megértéséhez. Scott (1988) gazdasági motor térségei, ezek fejlődőképes „hinterlandjai” viszonylag jól alkalmazhatók az Európai Unió és hazánk analógiájára. Hamilton (1999) értelmezése a globalizációról, mely szerint az „... a kulcsszereplök érdekérvényesitésének, a térröl alkotott elképzeléseik megvalósitásának teret adó folyamatok sorozata", egyértelmủ kapaszkodót nyújt a külföldi tőke hazai viselkedésének megértésében. Ezt a folyamatot bontja ki Dicken (1992) is, amikor a vállalati stratégia-építés megváltozott súlypontjairól értekezik, különös tekintettel a vállalatirányítás optimális sémájáról a multinacionális vállalatoknál ${ }^{2}$. Knox és Agnew (1998) világossá teszi, kemény területi verseny folyik a befektetési forrásokért, melyben folyamatosan bizonyítani kell a régió (térség, település) versenyképességét.

Porter (1996) kompetitív fejlödési elmélete, mint regionális versenyképességi elmélet, integrálja az agglomerációs gazdaságok, a növekedési pólusok, a gazdasági báziselmélet föbb megállapításait. Modelljének alapegysége a térségi gazdasági klaszter, melyben a tranzakciós költségek szintje alacsony, a szinergiák léptéke magas, a fejlődési determinánsok többsége kiemelkedő szintet ér el. Ám nem értelmezi a fejlödési determinánsokkal nem, vagy alig rendelkezö, a globális versenybe érintölegesen bekapcsolódó, technológiai értelemben leszakadó térségek fejlödési kilátásait. Egyedüli receptként a termelékenység folyamatos növelését ajánlja, mely magas szintű foglalkoztatás mellett elóállított, külsỏ piacokon értékesített feldolgozóipari termelést feltételez. ${ }^{3}$

Hipotézisünk: a magyar gazdaság rendszerváltozás utáni 15 éves fejlődési periódusát alapvetỏen a területi különbségek gyors, folyamatos növekedése, s ennek következtében az egyes települések, térségek közötti különbségek szintjének emelkedése határozta meg.

\section{Területi különbségek a rendszerváltás idöszakában}

Az államszocialista gazdasági irányítási rendszer alapvetö jellemzője volt a területi (elsősorban megyei) szinten megjelenő különbségek mérséklése, a területi kiegyenlítés politikája. A rendszer ideológiája alapján erre elsődlegesen az ipari uzzemek központilag vezérelt telepítésén keresztül volt mód, az első időkben (1965-1975 között) közvetlen állami döntések révén ${ }^{4}$, a későbbiekben (1975 után) közvetett eszközökkel, az önelszámoló egységekké alakított állami nagy ipari vállalatok telephely választásának területi preferenciáin keresztül.

A folyamat a vizsgált területi szinteken (tervezési-gazdasági régió, de föképpen a megye), illetve a vizsgált dimenziókban (beruházások alakulása, termelési mutatók, 
állóeszközök, jövedelmek, foglalkoztatás) a területi különbségek jelentős mérséklődését eredményezte. A felszín alatt azonban számos, később a területi egyenlőtlenségek növekedését hordozó folyamat is elindult. Egyik oldalról a markáns ipartalanítással ${ }^{5}$ a föváros (Budapest) fejlödését eltolták a poszt-indusztriális irányba ${ }^{6}$, ami a rendszerváltozás után strukturális előnyként jelentkezett a vidéki terekkel szemben. Másrészt, a vidéki tereken belül létrejött ÉK-DNY irányú iparosodott sáv (ún. Ipari tengely), mely elsődleges befogadója volt az ipari beruházásoknak ${ }^{7}$ (1.ábra).

\section{1. ÁBRA}

Magyarország gazdasági térszerkezete a rendszerváltás elött

Regional Economic Pattern of Hungary Before the Transition

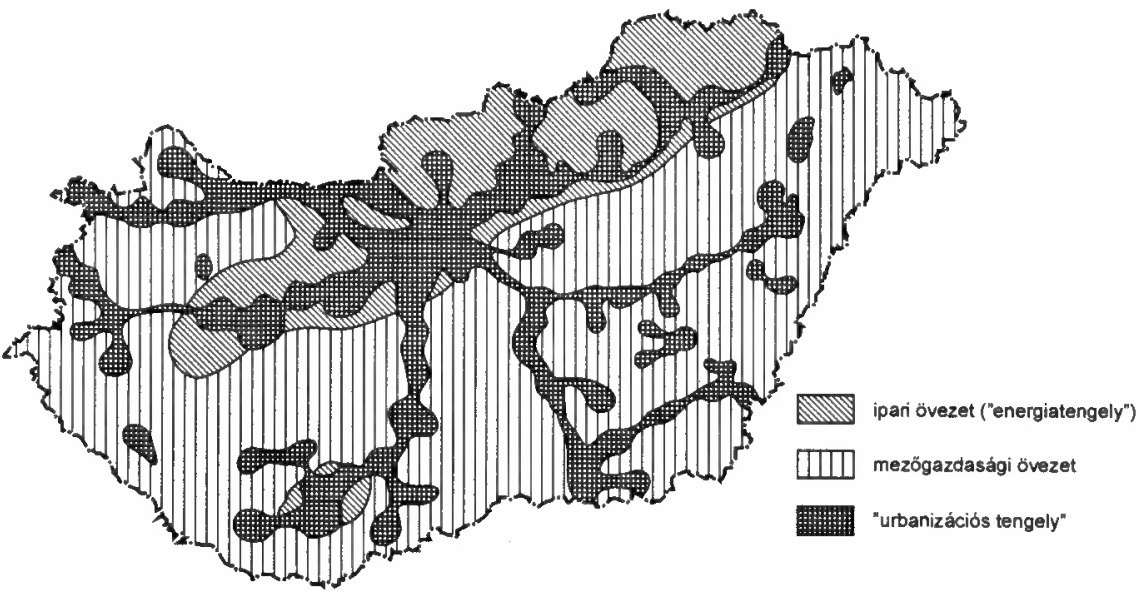

Forrás: Krajkó 1982.

Az ország többi részének meghatározó gazdasági szereplőit - néhány kivételtől eltekintve - a helyi szükségletekre termelö ipari ágazatok mellett elsősorban a munkaerőigényes feldolgozóipari ágazatok (élelmiszer és könnyüipar - föleg a szakképzetlen nőknek munkát adó textil- és ruházati-ipar), illetve az ún. „telephelyi ipar" alkották. Utóbbi tipikus szocialista nagyvállalati forma, a nagyvállalat kihelyezett termelöegysége volt, melyet egyetlen erőforrásra, a szabad, adott termelési feladatra betanítható munkaerőre létesítettek az ország gazdaságilag elmaradott (a kor értékrendjének megfelelően alul-iparosodott) térségében. E telephelyek sem képzett vezetőgárdával, sem döntési kompetenciával, sem szakmailag hozzáértő, kiszolgáló adminisztratív személyzettel nem rendelkeztek. A rendszerváltás után az állami tulajdonú nagyvállalatok önállósították e telephelyeket, melyek zöme képtelen volt talpon maradni a piacgazdaság körülményei között, miközben az anyavállalat továbbélése - komoly áldozatok mellett - általában sikeresen végbement.

A helyi gazdaságban kiegészítỏ jelleggel - a szabad vagy szezonálisan le nem kötött munkaerő foglalkoztatására - tanácsi vállalatok, TSZ-melléküzemágak alakultak. 
Elöbbiek a helyi tanácsok fejlesztési feladatainak végrehajtására szervezỏdtek, de zömük már a rendszerváltás elött, a „kvázi-piaci” körülmények között meg tudott erősödni, ezeket később jórészt hazai magánszemélyek privatizálták. Utóbbi csoportban, néhány közgazdász a háttéripar csiráit vélte felfedezni. Az illúziót, a rendszerváltás rombolta szét. A korábban önálló tevékenységet folytató iparosok számottevö részét háziipari vagy kisipari szövetkezetekbe tömörítették. A sikeresek ma is léteznek, a Harmadik Itália modelljét idéző specializált, magas minőségủ termékekkel. A kevésbé perspektivikusak vagy megszüntek a rendszerváltozás után, vagy tagjai ismét egyénileg (esetleg kisebb gazdasági társaságokban) folytatták a tevékenységüket.

A látszólagos kiegyenlítődés csapdáját az jelentette - amire a kor területi kutatói, közgazdászai már akkor felhívták a figyelmet -, hogy mindez a megyén (régión) belüli területi különbségek erőteljes kiéleződése révén valósult meg. Vági Gábor (1982) mutatta be a megyén belüli fejlesztési források elosztásának sémáját, mely elsődlegesen a megyeszékhely fejlödését preferálta, juttatott eszközöket a kisvárosok növekedésének serkentésére is, de a településállomány zömét alkotó falvak felé alig csordogált központi forrás. Mindez azért nem vezetett általános társadalmi feszültséghez, mert a hetvenes évektöl a megerösödỏ mezőgazdasági nagyüzemek erőteljesen hozzájárultak a falvakban beinduló fejlesztésekhez, egész jóléti intézményrendszert tartottak fenn, valamint a tagjaik számára lehetővé tett háztáji termelés olyan kiegészítő jövedelemforrást jelentett, mely érdemi életszínvonal emelkedést is eredményezett - jelentős túlmunka árán.

Az MSZMP munkás-szárnya (radikális baloldal), akik a nagyipari szervezett munkásrétegben, ezen belül a szakmunkás gárdában látta a párt fỏ társadalmi bázisát, érzékelték a vidék mezőgazdaság által generált felzárkózását, $s$ azonnali lépéseket követeltek. A kádári rezsim - egyik utolsó reális lépéseként - a vidék anyagi gyarapodását továbbra is támogatva, az ipari nagyüzemi dolgozók számára is lehetővé tette a munka melletti kereseti lehetőséget, a gazdasági munkaközösségek rendszerének engedélyezésén - kezdetben támogatásán - keresztull 1982-től. Ez a váltás a teljesítményelv, az egyéni teljesítmény anyagi elismerésének lehetőségét vitte bele a rendszerbe, illetve a hatékonyság logikáján keresztull a bizalmi elvre építkező, kis termelő, szolgáltató egységek létrehozását segítette elö ${ }^{8}$. A gyorsan terjedő „kvázi-magánvállalkozások”, majd 1984 után a valódi magáncégek (GMK, PJT, kisvállalatok egy része) terjedése az ország területi szerkezetének egy új dimenzió mentén történő megosztottságát vetítette elö (Nemes Nagy-Ruttkay 1989). A későbbi vizsgálatok (Rechnitzer 1993) a tér hasonló megosztottságáról tanúskodtak a vállalkozási aktivitásban, mely a nagycentrumok kiugró aktivitása mellett határozott Nyugat-Kelet lejtőt rajzolt ki.

A zömében kisméretü gazdasági egységek létrejötte azonban csupán egyik - látványos, de nem a leghatékonyabb - alakítója volt a rendszerváltás nyomán formálódó új gazdasági térstruktúrának. A két meghatározó folyamatot a privatizációs ügyletek, valamint a zöldmezös beruházások jelentették, hiszen e két csatornán (s különösen az elsőn) nagyságrendekkel nagyobb tőkék mozogtak, mint a „vállal- 
kozási boom” esetében. A volt állami (tanácsi) vállalatok átalakítása és magánkézbe adása közvetlenül kevésbé formálta a térszerkezetet, hiszen a meglévő termelói kapacitások tulajdonosi körének cseréje ment végbe. Ám nem volt mindegy, hogy a magánosítás mikor történt, milyen ágazatot érintett, milyen tulajdonosi csoport került meghatározó döntési pozícióba, milyen vállalati stratégia mentén folytak a fejlesztések, ezek milyen eredménnyel jártak. A privatizáció esetében tehát a minőségi elemek határozták meg a vállalati szintủ sikert és alkalmazkodóképességet, $\mathrm{s}$ nagyobb távon tekintve akár egész települések, térségek fejlödési kilátásait is.

Míg a magánosítás esetében a meglévő kínálat orientálta a befektetői kört, a zöldmezős befektetések esetében a befektetői motivációtól függően a piac, a logisztikai helyzet, az elérhetőség, a meglévö szakmakultúra, vagy éppen a korábbról átörökölt kooperációs hagyományok mozgatták a befektetéseket. A privatizáció esetében a kínálat területi egyenlőtlensége, a folyamat kifutása erösítette a föváros és tágabb terének, valamint a Dunántúl északi megyéinek gazdasági pozícióját, ám a területi különbségek drasztikus kiélezödését a zöldmezös beruházások regionális eloszlása eredményezte. A befektetők által preferált térségek gyakorlatilag megegyeznek a privatizációnál jelzett térrel, azzal az eltéréssel, hogy a zöldmezös befektetések inkább a vidéki tereket, az osztrák-magyar határzónát, a Bécs-Budapest tengelyt, a föváros tágabb agglomerációs terét célozták.

Önmagukban a vállalkozások területi egyenlötlenségei, a privatizációs folyamat, de még a zöldmezös beruházások sem eredményezték volna a területi különbségek a valóságban bekövetkezett nagymértékü kiélezödését, ha nem párosultak volna a tőke által kevéssé preferált térségek húzóágazatainak válságával és leépülésével. Mind a korábbi iparosodott térségek egyoldalúan fejlett, nagy anyag-és energiaigényủ ipara, mind a nagyüzemi agrártermelésre, a rá épülő feldolgozói vertikumra és a könnyűiparra alapozott térségi gazdasági modell válságba került, melyböl sem a privatizáció, sem a szigetszerúen megjelenő, de érdemi katalizáló hatást ki nem fejtő zöldmezős beruházások nem tudták kilendíteni az érintett térségek gazdaságát, egészen a kilencvenes évek utolsó negyedéig. A válságterek és a dinamikus terek eröteljes térbeli elkülönülése eredményezte az országban megjelenö egyenlötlenségeket, melyek lényegesen átformálták a rendszerváltás elötti területi struktúrát, s hosszabb időre konzerválták a belső megosztottságot (2. ábra).

A piaci erök a rendszerváltást követö összes jellegzetes idöszakban - válság és visszaesés, a térben és időben eltolódással jelentkező stabilizáció, a gyors gazdasági növekedés időszaka, illetve az ezredfordulót követö lassúbb gyarapodás periódusa a regionális különbségek növelése irányába hatottak. Ez a differenciálódás mind a föváros-vidék, mind a vidéken belüli különbségek, mind a településhálózat elemei közötti fejlettségi eltérések kapcsán világosan láthatók. Az eddigi tapasztalatok szerint az alapvetỏen neoliberális elvek alapján múködö magyar piacgazdaság spontán eröi világosan és egyértelmüen különbségeket generálnak, megosztottságot teremtenek, ahelyett, hogy integrálnák az eltérö adottságú, különböző komparatív elönyöket felvonultató térségeket. 
Divergencia vagy konvergencia - Az átmenet gazdasági térfolyamatainak mérlege földrajzos szemmel. Tér és Társadalom 21. évf. 2007/1. 35-51. p.

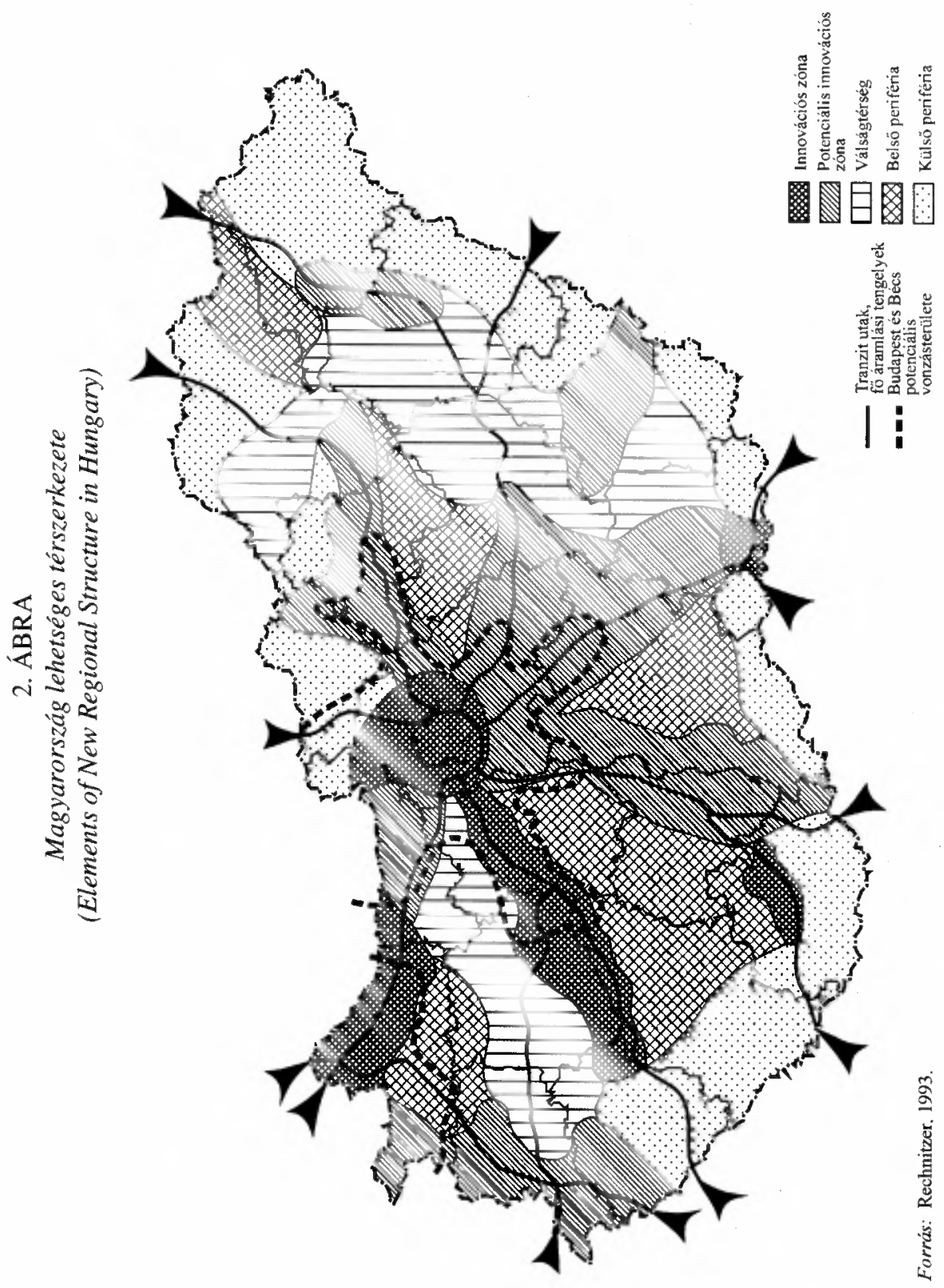


Divergencia vagy konvergencia - Az átmenet gazdasági térfolyamatainak mérlege földrajzos szemmel. Tér és Társadalom 21. évf. 2007/1. 35-51. p.

A korszak állami fejlesztési politikája is neoliberális elveken nyugodott, melyben az ágazati szemlélet dominált a területivel szemben. Ez a megközelítés az ország, mint egész versenyképességének növelésére, az Európai Unió átlagát meghaladó gazdasági növekedési ütemre, a termelékenységi szakadék csökkentésére helyezte a fő hangsúlyt, s a társadalmi, illetooleg a térségi szinten megjelenő feszültségeket (munkahelyek eltünése, befektetések hiánya, alacsony szintủ vonzerók) eseti, elégtelen léptékú beavatkozásokkal kezelték. Ennél nagyobb probléma, hogy az állam, mint meghatározó

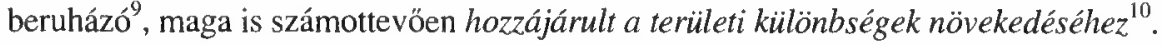

Az 1996-ban törvényi hátteret kapó területfejlesztés és területrendezés a forráshiány következtében, alig volt képes érdemi fejlesztéseket finanszírozni, az egyes térségek fejlödési pályáját számottevően befolyásolni. Az Orbán-kormány által indított Széchenyi Terv a felszínen mutatkozó látszat (beadott és sikeres pályázatok száma, elnyert források nagysága) ellenére, a gazdasághoz közvetlenül kötödő programokban tovább növelte az amúgy is számottevö különbségeket az ország területi egységei, települései között.

Bár a 2004-2006-os évre szóló Nemzeti Fejlesztési Terv hatásrendszerét ma még nem lehet látni, a kiírt pályázatok tematikája a korábbi logika mentén formálódott ki, ami aligha vezet egy területileg kiegyenlítettebb fejlödéshez az Uniós források (kiemelten a Strukturális Alapok) bevonásán keresztül. A magyar költségvetés pozíciója csekély mozgásteret hagy a hazai finanszírozású fejlesztési programok számára, az Uniós források lekötését célzó nemzeti társfinanszírozás elóteremtése az egyes tárcák forrásait erősen megterheli. Ilyen körülmények között az ágazatok részéról a területi elvet előtérbe helyezó fejlesztési politikát várni naivitás, s ezen nem változtat, hogy a területfejlesztés meghatározó elemei a régiók a korábbi évekkel összevetve nagyobb saját forrásokkal rendelkezhetnek. (A központi kormányzattól átvett források átlagosan 92\%-a feladatra kapott, nem szabad felhasználású, inkább ágazati, mint regionális érdekeket szolgál.)

A gazdasági indikátorok területi alakulását a jövedelmi viszonyok alakulása is követi. Ennek oka nem csupán az, hogy a dinamikus térségekben magasabb a keresök aránya és kisebb a munkanélkülieké, hogy ott jobban megfizetett munkások dolgoznak. Még a területi különbségeket elvben kiegyenlítö - s mérete miatt sok esetben kritizált - közalkalmazotti szféra esetében is érdemi területi különbségek mutatkoznak a gazdagabb és szegényebb térségek, települések között, s hasonló mértékü különbségek mutatkoznak a nyugellátás esetében is. Az állam által ellenörzött és meghatározott szférákban is jelentkezik - a piaci szféránál mérsékeltebb Nyugat-Kelet lejtö. A jövedelmek alacsonyabb szintje nem párosul alacsonyabb megélhetési költségekkel. A leszakadó régiókban élő családok meghatározó vagyontárgyainak (föld, lakás vagy ház) értéke töredéke a dinamikus térségekben lévőknek, ami korlátozza a területi mobilitási hajlandóságot a stagnáló, lemaradó területekről a felfutó, sikeresnek tekintett térségek irányába.

A rendszerváltás korszaka egyértelmüen a területi differenciálódás idöszaka Magyarországon, mely másfél évtized elteltével azokat a területi modelleket látszik igazolni, melyek a mérsékelt induló eltérések kumulálódásából építkezö eröteljes regionális differenciálódást jelezték elöre, s e különbségek tartós fennmaradását prognosztizálták. 


\section{Átfogó indexek a területi különbségek alakulásának mérésére - GDP, HDI}

A terủleti GDP megyei szintü adatait 1994-2004 közötti időszakban értékelhetjük ${ }^{\prime \prime}$. Ennek alapján úgy tünik (1. táblázat), hogy a PPP-ben (Purchasing Power Parity - vásárlóerő paritás) mért, s az EU 15-hỏz viszonyított értékek a vizsgált időszakban az ország térbeli megosztottságának erősödését jelzik. Miközben az ország egésze a 2004-ben csatlakozott új tagállamok közủl az egyik leggyorsabb felzárkózási pályát futotta be, addig négy megyében abszolút értelemben leszakadás, $s$ további legalább 6 megyében minimális (11 év alatt kevesebb, mint 4\%-os) felzárkózás történt. Látványos és érdemi felzárkózás (11 év alatt legalább 10\%) öt megyében történt, melyek mindegyike az ország központi régiójában, vagy az Északnyugat-Dunántúlon fekszik, ezen belül is kiemelkedö a föváros fejlódési üteme, illetve az utóbbi évek felfutása nyomán Komárom-Esztergom megye mutatóinak látványos javulása.

\section{TÁBLÁZAT}

Teriuleti GDP (PPS), 1994; 1996; 2000; 2004

(Regional GDP per Capita in Hungary, PPS)

\begin{tabular}{|c|c|c|c|c|c|}
\hline \multirow{2}{*}{ Megye } & 1994 & 1996 & 2000 & 2004 & $\begin{array}{c}2004- \\
1994 \\
\end{array}$ \\
\hline & $E U 15=100$ & $E U 15=100$ & $E U 15=100$ & $E U 15=100$ & $\begin{array}{c}\text { Változás } \\
(\%)\end{array}$ \\
\hline Budapest & 83,3 & 92,5 & 102,4 & 113,8 & 30,5 \\
\hline Pest & 35,2 & 35,7 & 39,5 & 49,4 & 14,2 \\
\hline Fejér & 44,4 & 51,0 & 60,1 & 54,4 & 10,0 \\
\hline $\begin{array}{l}\text { Komárom- } \\
\text { Esztergom }\end{array}$ & 37,0 & 43,9 & 42,2 & 62,2 & 25,2 \\
\hline Veszprém & 36,5 & 39,8 & 42,5 & 43,5 & 7,0 \\
\hline Györ-M.-Sopron & 49,0 & 54,0 & 67,8 & 64,1 & 15,1 \\
\hline Vas & 48,6 & 53,8 & 57,7 & 55,9 & 7,3 \\
\hline Zala & 43,9 & 45,5 & 42,3 & 50,5 & 6,6 \\
\hline Baranya & 38,9 & 38,0 & 38,2 & 41,2 & 2,3 \\
\hline Somogy & 35,6 & 36,5 & 33,9 & 38,0 & 2,4 \\
\hline Tolna & 43,9 & 44,0 & 41,1 & 39,0 & $-4,9$ \\
\hline Borsod-A.-Zemplén & 31,9 & 34,3 & 32,4 & 37,2 & 5,3 \\
\hline Heves & 32,8 & 36,2 & 35,9 & 40,7 & 7,9 \\
\hline Nógrád & 28,7 & 27,9 & 27,3 & 30,0 & 1,3 \\
\hline Hajdú-Bihar & 38,4 & 38,2 & 36,0 & 42,2 & 3,8 \\
\hline Jász-N.-Szolnok & 36,5 & 36,8 & 33,5 & 35,9 & $-0,6$ \\
\hline Szabolcs-Sz.-Bereg & 27,3 & 28,7 & 27,0 & 31,0 & 3,7 \\
\hline Bács-Kiskun & 35,6 & 36,8 & 33,5 & 37,8 & 2,2 \\
\hline Békés & 37,5 & 37,1 & 33,1 & 33,9 & $-3,6$ \\
\hline Csongrád & 43,5 & 45,0 & 41,6 & 42,9 & $-0,6$ \\
\hline
\end{tabular}

Forrás: A KSH és az Eurostat adatai alapján saját számítás. 
Az 1994-2004 időszak egyértelmủ folyamatait némileg árnyalja, hogy 2004-ben a mezőgazdaság látványos ( $52 \%$-os) GDP bövülése nyomán számos megye „,közelebb keruilt" fejlettségi szintjében az országos átlaghoz, esetenként akár 0,5-1\%-kal is. Hogy a folyamat tényleges fordulatot jelez-e vagy sem, ezzel vélhetően meg kell várni még további egy-két év területi GDP adatait, de az agrár ágazat országos teljesítményének visszaesése a 2005 -ös évben inkább azt jelzi, hogy egyszeri változásról van szó.

\section{TÁBLÁZAT}

Területi HDI - Humán fejlettségi index

(Regional HDI in Hungary)

\begin{tabular}{lcccc}
\hline \multicolumn{1}{c}{ Megye } & 1990 & 1996 & 1999 & 2001 \\
\hline Budapest & 0,899 & 0,915 & 0,866 & 0,865 \\
Pest & 0,448 & 0,471 & 0,790 & 0,802 \\
Fejér & 0,656 & 0,709 & 0,821 & 0,828 \\
Komárom-Esztergom & 0,517 & 0,562 & 0,805 & 0,802 \\
Veszprém & 0,685 & 0,733 & 0,805 & 0,806 \\
Györ-Moson-Sopron & 0,818 & 0,883 & 0,841 & 0,839 \\
Vas & 0,652 & 0,880 & 0,823 & 0,825 \\
Zala & 0,593 & 0,684 & 0,813 & 0,804 \\
Baranya & 0,452 & 0,451 & 0,798 & 0,795 \\
Somogy & 0,324 & 0,280 & 0,789 & 0,784 \\
Tolna & 0,462 & 0,376 & 0,805 & 0,799 \\
Borsod-Abaúj-Zemplén & 0,261 & 0,169 & 0,788 & 0,782 \\
Heves & 0,508 & 0,524 & 0,800 & 0,789 \\
Nógrád & 0,419 & 0,218 & 0,776 & 0,772 \\
Hajdú-Bihar & 0,359 & 0,406 & 0,797 & 0,792 \\
Jász-Nagykun-Szolnok & 0,411 & 0,330 & 0,789 & 0,785 \\
Szabolcs-Szatmár-Bereg & 0,029 & 0,039 & 0,773 & 0,764 \\
Bács-Kiskun & 0,295 & 0,322 & 0,796 & 0,787 \\
Békés & 0,519 & 0,543 & 0,796 & 0,789 \\
Csongrád & 0,592 & 0,610 & 0,815 & 0,806 \\
Ország & 0,584 & 0,595 & 0,817 & 0,814 \\
\hline Foras:Nemes-Nagy Jakoin & & & & \\
\hline
\end{tabular}

Forrás: Nemes-Nagy, Jakobi (2003); UNDP-jelentés (2003).

A GDP mellett használatos - és a nemzetközi gazdasági irodalomban egyre elfogadottabb - komplex, a fejlettséget egyetlen számba sürítő index, a HDI hazai alkalmazására relatíve kevés példa van a területi kutatásokban. Nemes-Nagy és Jakobi (2003) tett kísérletet egy egyszerủsített módszertan alapján előállított index területi kiszámítására, ahol az 1990, 1996, 1999 és 2001-es évekre készítettek becslést a regionális különbségek alakulására. Az első két, illetve az utolsó két időszak eltérő módszertani bázison készített számításai miatt a kapott adatok a teljes idősorra nem hasonlíthatók össze, csak páronkénti összevetésre van lehetöség. A születéskor 
várható átlagos élettartamot, iskolázottsági mutatókat ${ }^{12}$ és az életszínvonalat sürítő HDI (2. táblázat) a kilencvenes évek első felére növekvő, az ezredforduló körüli évekre stagnáló területi különbségeket jelez. A HDI - bár lényegesen alacsonyabb szintü belső különbségeket kimutatva - lényegében a gazdasági fejlődés által létrehozott területi struktúrát rajzolja ki.

Nemes Nagy és Jakobi nyomán az elmúlt másfél évtized nagy statisztikai felvételeihez (Népszámlálás, illetve Mikrocenzus) igazodva magunk is kísérletet tettünk egy azonos módszertan szerint készített HDI területi index kiszámítására, valamint az általa jelzett regionális különbségek értelmezésére (3. táblázat).

\section{TÁBLÁZAT}

Terïleti HDl értékek, 1990; 1996; 2000; 2004

(Corrected Regional HDI in Hungary, [on the Base of 14 Indicators])

\begin{tabular}{lllll}
\hline \multicolumn{1}{c}{ Megye } & 1990 & 1996 & 2000 & 2004 \\
\hline Budapest & 0,953 & 0,983 & 0,921 & 0,952 \\
Pest & 0,728 & 0,691 & 0,804 & 0,764 \\
Fejér & 0,758 & 0,724 & 0,802 & 0,743 \\
Komárom-Esztergom & 0,774 & 0,711 & 0,828 & 0,763 \\
Veszprém & 0,759 & 0,753 & 0,899 & 0,738 \\
Györ-Moson-Sopron & 0,815 & 0,805 & 0,931 & 0,783 \\
Vas & 0,801 & 0,749 & 0,908 & 0,747 \\
Zala & 0,727 & 0,714 & 0,754 & 0,741 \\
Baranya & 0,711 & 0,660 & 0,732 & 0,676 \\
Somogy & 0,710 & 0,647 & 0,691 & 0,643 \\
Tolna & 0,733 & 0,632 & 0,715 & 0,688 \\
Borsod-Abaúj-Zemplén & 0,700 & 0,599 & 0,639 & 0,600 \\
Heves & 0,715 & 0,656 & 0,726 & 0,689 \\
Nógrád & 0,698 & 0,634 & 0,666 & 0,674 \\
Hajdú-Bihar & 0,666 & 0,615 & 0,656 & 0,651 \\
Jász-Nagykun-Szolnok & 0,685 & 0,630 & 0,666 & 0,630 \\
Szabolcs-Szatmár-Bereg & 0,627 & 0,548 & 0,596 & 0,590 \\
Bács-Kiskun & 0,685 & 0,636 & 0,697 & 0,652 \\
Békés & 0,723 & 0,665 & 0,720 & 0,648 \\
Csongrád & 0,741 & 0,698 & 0,839 & 0,715 \\
Ország & 0,766 & 0,673 & 0,747 & 0,708 \\
\hline
\end{tabular}

Forrás: Saját számítás.

A nemzetközi standard-hez közelítve az index tartalmát egy 14 tényezös (négy alkomponensbe összevont) adatstruktúrát állítottunk elő a következő módon:

- Demográfia: születéskor várható élettartam nemenként

- Iskolázottság: 10-X éves korosztályból iskolázatlanok aránya, legalább érettségivel rendelkezők aránya a 18-X éves népességből, átlagos elvégzett osztályszám (1990-re és 2001-re) 
- Lakáskörülmények: komfort nélküli lakások aránya, négy vagy több szobás lakások aránya, az adott időszakban épített lakások aránya 1000 lakosra

- Jövedelmi viszonyok: adózók száma 1000 lakosra, egy főre jutó SZJA, nettó jövedelem, területi vásárlóerö ${ }^{13}$.

A területi különbségek gyors növekedése, mely a kilencvenes évek első felét jellemezte, számításaink szerint nem állt meg, s nem fordult ellentétébe az 1996-2000 vagy a 2000-2004 időszakban sem, bár kétségtelenül a differenciálódás mértéke lényegesen csökkent. Ez azonban számunkra kevésbé a területi kiegyenlítỏdés közeli jövőben várható elindulását, sokkal inkább a kialakult térstruktúra rögzülését, a komparatív elönyök stabilizálódását és a térbeli fejlödési pályák divergenciáját jelzik. A HDI magas és az országos átlagot lényegesen meghaladó értékei továbbra is kizárólagosan a Központi Régiót, valamint a Nyugat- és Közép-Dunántúl megyéit jellemzik, s a két megyecsoport között lényegében nincs átmenet.

A területi különbségeket mérỏ indexek alakulása alapjaiban alátámasztja a tanulmány elején felvetett hipotézist. Ugyanakkor azt is látni kell, hogy a központi kormányzat - a piaci erők túlsúlya ellenére - hatásos eszközökkel rendelkezik a térfolyamatok alakítására, bár ezek hosszú távú versenyképességi és területi hatásai kérdésesek. A hazai politika elsősorban a jövedelmi helyzetbe való beavatkozással hatott a területi különbségek alakulására (sorozatos minimálbér emelések 1999 után, közalkalmazotti és köztisztviselöi bérrendezések, kedvezmények változó rendszere). Ezek - azon túl, hogy kevéssé tekinthetök piackonform beavatkozásoknak - általában csak átmenetileg, rövid idöre térítették el a területi folyamatokat, hatásuk lefutása egy-két évre tehetỏ. Ugyanakkor a támogatások mellett viszonylag jelentős volumenben megjelenő fejlesztési források (területfejlesztés 1996-tól, Széchenyi Terv 2000-2001, Elöcsatlakozási Alapok 2002-2006, 1. NFT 20042008) területi felhasználása már nem mutatott tudatos területi preferenciát, koncentrációt, nem jelentkeztek a kívánatos szinergia hatások, vagy csupán mértéke volt elégtelen a globálisan ható folyamatok ellensúlyozására.

\section{Záró gondolatok}

A centrum-periféria kapcsolatrendszert Ash Amin (1976) a hatalom egyenlötlen földrajzi megoszlásából vezette le. Míg a magrégió az egyenlötlen csere folyamatán keresztül koncentrálja a gazdasági hatalmat, ellenörzi a technikai haladást és a termelési folyamatot, addig a periféria felöl a mobilizálható javak, erőforrások, valamint a termelés során keletkezett értéktöbblet áramlik a centrum irányába, hogy támogassa annak további fejlödését. A periféria autonóm - a centrumtól független fejlödése egyre nehezebbé válik, annak következtében, hogy a centrum a saját érdekei mentén alakítja a politikai döntéshozatal egész mechanizmusát ${ }^{14}$.

Storper és Walker (1989) a területi különbségek fỏ alakítójának a termelés területi expanzióját, a globális telephelyválasztást tartja, mely a nyolcvanas évtizedre a kereskedelemnél (egyenlőtlen csere) fontosabb okává vált az egyenlőtlen területi fejlödésnek. Krugman (1991) ezt azzal egészíti ki, hogy agresszív ágazati és területi politika, 
valamint új háttérfeltételek mellett esély nyịhat új területi egységek felemelkedésére, a földrajzi koncentráció meglévő térstruktúrájának újrarajzolására. Krugman érvelését lecsupaszítva arról van szó, hogy a mobil tőke számára kell kiemelkedően kedvezö letelepedési feltételeket kínálni, biztosítva a magas szintủ megtérülés lehetöségét ${ }^{15}$.

A valóságban a domináns társadalmak képesek csupán szerves, belső erőforrásaik optimális szintet közelító kiaknázásán alapuló fejlödésre, a függỏ társadalmak csak a domináns szereplök szükségleteinek mértékében, azt mintegy visszatükrözve képesek növekedésre. A „feltörekvő piacok” országainak példája jelzi, hogy önmagában látványos elörelépésük, melyet a piacgazdaság kiépítése és múködtetése révén magukénak tudhatnak, eröteljesen függ a globális és szupranacionális szervezetek (fóképpen a globális pénzügyi piacok) kontrolljától. Ez a fejlödési pálya komoly társadalmi veszélyeket rejt magában, hiszen az aszimmetrikus kapcsolatrendszer révén a függő ország társadalmi struktúrája dezintegrálódhat, miközben csupán a felszínét képes adaptálni a domináns társadalmat müködtető rendszernek.

A helyi gazdaság meghatározó szereplöivé növekvő multinacionális cégek leányvállalatai, a velük kapcsolatba kerülỏ helyi beszállítók, alvállalkozók a külső döntési központok által koncentrált és mozgatott tökeáramlás fogaskerekei, melyek az extraprofit kivonása érdekében kerültek bele a globális gazdasági folyamatok sodrába. A helyi szint döntéshozóinak mozgástere eröteljesen leszükült, melyet nemzetközi és nemzeti szintủ szabályozási rendszerek, intézmények egész hálózata ellenőriz. Ugyanakkor igaz, hogy a centrum fejlödése függ az alulfejlett periféria lététől, a területi egyenlötlenségek tartós fennmaradásától. Ez a kölcsönös függőség bár erősen féloldalas, mégis némi teret és lehetöséget ad a helyi kezdeményezések, akciók, fejlesztési lépések indításakor. Ennek következtében a függő gazdaságokban is bekövetkezhet valódi fejlödés, felzárkózás a fejlettebb régiókhoz, mérséklődhet az egyoldalú alávetettség. Sikeres szerkezetváltás (mely egyúttal gazdaságpolitikai fordulatot is feltételez) esetén akár feljebb is lehet kapaszkodni a globális ranglétrán.

A nagyvárosi régiók függősége a külső perifériáktól erősebb a látszólagosnál üzenték a Brandt-Jelentések $(1980,1983)$ - hiszen amíg a periféria választhatja a nagyfokú elzárkózást a globális trendektöl, vagy kapcsolódhat más, kedvezőbb fejlödési lehetőséget kínáló centrumok irányába, lazítva egyoldalú függőségét a magrégiótól, növelve saját mozgásterét, addig a központi szerepủ metropoliszok esetében a globális folyamatok elöl való elzárkózás fel sem merülhet, mint alternatíva. Ha perifériájuk lecsökken, akkor kínálati pozíciójuk a globális mobil tőke felé romlik, mely csökkenö volumenủ befektetésekben, a versenypozíció romlásában jelentkezik.

A gazdaságot mozgató mobil tőke bevonásához már nem elégséges a hagyományos gazdasági erőforrások kínálata, egyre fontosabbá válik az extern feltételek minél teljesebb körének magas színvonalú biztosítása, legalább a megcélzott tevékenységek esetében. Ennek eredményeként térben koncentrált, specializált lokális vagy térségi gazdaság kialakítására nyilik mód és lehetőség. A térségi szinten jelentkező alulfejlettség általában kiegyenlítetlen térstruktúrával párosul. Az egyes területi egységek saját fejlödésük zálogát sokkal inkább látják a távoli centrummal 
ápolt intenzív kapcsolatokban, mint a szomszédos térségekkel való együttmüködésben, a problémák közös megoldásában ${ }^{16}$.

A marxista földrajzi megközelítés (Harvey 1982; Smith 1984) a hatalom egyenlötlen megosztásáról beszél, mely területi egyenlötlenségeket involvál, legyen szó közvetlen vagy közvetett ellenörzési lehetöségröl, a létrehozott hálózatokon keresztül a tér meg-, illetve újjászervezéséröl, vagy a technikai, innovációs előnyök kihasználásáról. A hatalom egyenlőtlen megoszlásának okát a tulajdonviszonyokban, nevezetesen a termelési tényezök egyenlötlen tulajdonlásában látják. A legnagyobb hatalommal bíró szereplök megszervezik a teret és a benne zajló folyamatokat, maguk felé terelik a hasznot, s ez osztálykülönbségeket generál, mely társadalmi, gazdasági és politikai konfliktusokon keresztül manifesztálódik. A kiváltságos kisebbség az állami apparátust is felhasználja céljai eléréséhez, miközben részt enged neki a haszonból ${ }^{17}$.

Az egyenlötlen területi fejlödés messzemenökig kihasználja az egyes térségek fejlettségében jelentkezö időbeni és strukturális különbségeket. Ma Európa legfejlettebb városrégióit döntően a poszt-indusztriális fejlödési pálya jellemzi, miközben a nyolcvanas években látványos felzárkózást mutató régiókat (Dél-Németország, DélFranciaország, Katalónia, Harmadik Itália) a poszt-fordista elveken alapuló ipari termelés, a rugalmas specializáció modellje lendítette dinamikus fejlődési pályára. Az új termelési modell erőteljes gazdasági szerkezetváltás mellett ment végbe, új sok esetben mesterségesen letelepített - húzóágazatok váltak a térségi gazdasági dinamika hordozóivá. Ez a felfutás csak átmeneti lehet, az olcsóbb bérủ versenytársak mára csaknem minden ágazatban - leszámítva a globális összehasonlításban is élenjáró tevékenységeket - komparatív előnyökkel rendelkeznek. Ahogyan Neil Smith (1984) fogalmazott, a töke mozgásában kimutatható az oszcilláció a mindenkori alulfejlett régiók közőtt, ami érdemben nem alakítja át a meglévő hatalmi viszonyokat.

A magyar gazdaságban zajló centrum és perifériaképzödés folyamata nem független a fent leírt globális folyamatoktól. Miközben a kormányzati politikák elsőrendü prioritása a mielőbbi sikeres felzárkózás az európai kontinens vezető gazdaságaihoz, addig az ország nagy része képtelen felvenni a főváros által diktált fejlödési ütemet, jelentős része pedig abszolút értelemben is leszakadóban van az Uniós átlagtól. Amikor a kormányzati politika fontosságát minden releváns térelmélet kiemelten kezeli, a hazai irányítási és szabályozási gyakorlatot a piac mindenhatóságába vetett (meghaladott) nézetek uralják. Ad-hoc intézkedéseken kívül - melyek akut válsághelyzetek kezelését hivatottak szolgálni - kormányzati szinten nem érhetô tetten komplex területi politika, igaz a parlamenti és parlamenten kívüli politikai erök részéröl sem érkezett még e terület kihívásaira hatékony válaszként értelmezhető stratégia. 


\section{Jegyzetek}

' A tanulmány a 2006. november 18-án, az ELTE-n tartott Regionális Modellek c. tudományos konferencián elhangzott elöadás írott formája.

${ }^{2}$ Hasonló következtetésekre jut Dunning (1988) eklektikus elmélete, a működőtőke beruházás motivációinak elemzése kapcsán.

${ }^{3}$ A földrajz meghatározó iskolái a hetvenes évek „cultural tum"-je óta fokozatosan fordultak el a területi modellektöl (leghatározottabban az ún. „szociologizáló irányzatok” és a radikálisok), azok mechanikussága, formalizmusa miatt. A modellekkel szemben felhozott leggyakoribb érv a valós tér figyelmen kívưll hagyása, a térfolyamatok léptékétöl való eltekintés volt (Martin 1999).

${ }^{4}$ Bár az MSZMP KB (Magyar Szocialista Munkáspárt Központi Bizottsága) már 1958-ban határozatot hozott a „vidéki iparosításról”, a megvalósítás a hatvanas évek közepétöl indult csupán.

${ }^{5}$ Az ötvenes évek közepén - dacára a nagy ipari centrumok elsö építési hullámának - a föváros súlya az ipari keresökböl még mindig $40 \%$ felett mozgott, miközben az ország lakosságából alig 19\%-kal részesedett. A folyamat végére - a kora nyolcvanas években - Budapest alig $28 \%$-át adta az ipari keresőknek, miközben a népességen belüli súlya $20 \%$-ra emelkedett.

${ }^{6}$ A nyolcvanas évtized elejére tehetỏ a fordulat, melytöl kezdve a föváros és a vidék dinamikus tereinek fejlődése elválik egymástól. Előbbit a szolgáltató tevékenységek dinamizálják, utóbbiakban a feldolgozóipar aktuális húzóágazatai voltak a siker meghatározói.

${ }^{7}$ Miután a korban elsődlegesen ipari beruházásokhoz kötötten volt lehetőség a lakásállomány, az intézményhálózat, az infrastrukturális hálózatok, a jóléti rendszerek fejlesztésére, egy kiemelt állami nagyberuházás megszerzése kiugró fejlödési lehetőséget kínált az adott telepưlésnek és szükebb térségének.

${ }^{8} \mathrm{~A}$,második gazdaság" megléte segítette a későbbi piaci átmenetet, a văllalkozás-alapítást.

${ }^{9}$ Az állam által végrehajtott invesztíciók az összes beruházási volumen 20-25\%-át tették ki, szemben a gazdasági szereplök közel kétharmados súlyával.

${ }^{10}$ Számítások szerint az állam szerepe a területi különbségek növelésében 17-18\%-ra volt tehető a kilencvenes évtized folyamán.

${ }^{11}$ Bár a GDP számítás módszertana az időszak folyamán három alkalommal is érdemben változott, ez az időbeli összehasonlításban nem okozott áthidalhatatlan gondokat.

${ }^{12}$ A szerzök az írni-olvasni tudás rátáját, valamint az adott iskolai szintet elvégző népesség arányát vonták egy iskolázottsági mutatóba.

${ }^{13}$ A GfK Hungária által évenként-kétévente készített számítás 2004-ig egyértelmủen a területi kủlönbségek növekedését jelzi, bár az ezredforduló utáni évekre a differenciálódás üteme csökkent!

${ }^{14}$ A kritikusok szerint hibás az ok-okozati lánc, mely szerint a hatalom társadalmi koncentrációja maga után vonja a térbeli csomóponti szerep kialakulását is.

${ }^{15}$ Bár a termelési folyamat dekoncentrációja vagy akár a döntéshozatal egyes elemeinek decentralizációja látványosan újrarajzolhatja a gazdaság globális térképét, a termelési lánc kulcsfontosságú elemeinek kontrollját megtartva nem következik be érdemi változás a világgazdaságban.

${ }^{16}$ A fejlödö országokra Slater (1975) által kidolgozott példa alkalmazható a hazai térfolyamatokra, a térségek kommunikációs gyakorlatára.

${ }^{17}$ Ez nem az állami apparátus korrumpálását jelenti! A tökének kedvezö döntések meghozatala és végrehajtatása fejében információkhoz való hozzáférést, a döntésekben való részvétel lehetöségét kínálják.

\section{Irodalom}

Amin, A. (1976) Unequal development. - Monthly Review Press. New York, London.

Boudeville, J.-R. (1966) Problems of regional economic planning. Edinburgh University Press, Edinburgh. Brandt-Report (1980) North-South: a programme for survival. Pan Books, London.

Brandt-Report (1983) Common crisis: North-South cooperation for world recovery. Pan Books, London, MIT Press, Cambridge, MA.

Dicken, P. (1992) Global shift. The internationalisation of economic activity. Paul Chapman, London.

Dunning, J. (1988) The theory of international production. - The International Trade Journal 3. 269-296. o. Edquist, C. (1997) Systems of innovation. Cassel, London.

Fóti K. (szerk.) (1999) Az emberi eröforrások jellemzöi Magyarországon 1999. MTA VKI, Budapest. 
Friedmann, J. (1966) Regional development policy: a case study of Venezuela. MIT Press, Cambridge MA. London.

Friedmann, J. (1973) Urbanisation, planning and regional development. Beverly Hills Cal., London.

Haggett, P. (1983) Geography. A modern synthesis. Harper-Collins, New York.

Hamilton, I.F.E. (1999) A globalizáció és a lokális gazdasági fejlődés, - Helyek, terek, régiók. Nemes Nagy J.(szerk.) ELTE Regionális Földrajzi Tanszék, Budapest. 87-101. o.

Harvey, D. (1982) The limits to capital. University of Chicago Press, Chicago.

Haynes, K.E.-Fortheringham, A.S. (1988) Gravity and spatial interaction models. Scientific Georgaphy 2. SAGE Beverly Hills, London, New Delhi.

Krajó Gy.-Abonyiné Palotás J. (1982) Magyarország gazdaságföldrajza: Segédanyag a Magyarország gazdaságföldrajza c. kollégium gyakorlatához. Tankönyvkiadó, Budapest.

Knox, P.-Agnew, J. (1998) The geography of the world economy. $3^{\text {rd }}$ edition. Arnold, London. Routledge, Chapman\&Hall, New York.

Krugman, P. (1991) Geography and trade. MIT Press Cambridge, MA.

Lasuén, J.R. (1969) On growth poles. - Urban Studies 6. 137-161. o.

Lasuén, J.R. (1973) Urbanisation and development. The temporal interaction between geographical clusters. - Urban Studies. 10. 163-188. o.

Lundvall B. (ed.) (1992) National systems of innovation. Pinter, London.

Martin R. (1999) The new "geographical turn" in economics: Some critical reflections. - Cambridge Journal of Economics 23.65-91. o.

Myrdal, G. (1957) Rich lands and poor. Harper\&Row, New York.

Nelson R. - Winter S. (1982) An evolutionary theory of economic change. Harvard University Press, Cambridge MA.

Nemes Nagy J.-Ruttkay É. (1989) A második gazdaság földrajza. OT TGI, Budapest.

Nemes Nagy J. (1987) A regionális gazdasági fejlödés összehasonlitó vizsgálata. Akadémiai Kiadó, Budapest.

Nemes Nagy J. (1998) A tér a társadalomkutatásban. Bevezetés a regionális tudományba EmberTelepullés-Régió 2. Hilschler Rezső Szociảlpolitikai Egyesület, Budapest.

Nemes Nagy J.-Jakobi Á. (2003) A humán fejlettségi index (HDI) megyék közötti differenciáltsága 1999-ben. Budapest, ELTE, Kézirat.

Nyitrai F-né. (2001) A humán és a gazdasági fejlödés. Nemzetközi összehasonlítás. KSH, Budapest.

Paelinck, J. (1965) La théorie du développement polirisé. - Economie Régionale. 159. 203-254. o.

Perroux, F. (1955) Note sur la notion de pole de croissance. - Economie Appliquée. 7. 307-320. o.

Porter, M. (1996) Competitive advantage. Agglomeration economies and regional policy. - International Regional Science Rewiev 1-2.85-94. o.

Pottier, P. (1963) Axes de communication et développement économique. - Revue Économique. 14. 58-132. o. Rechnitzer J. (1993) Szétszakadás vagy felzárkózás. A térszerkezetet alakitó innovációk. MTA RKK, Györ.

Rechnitzer J.-Smahó M. (2006) Regional Characteristics of Human Resources in Hungary During the Transition. Discussion Papers Series. MTA RKK, Pécs. 50. o.

Richardson, H.W. (1980) Polarisation Reversal in Developing Countries. - Papers of the RSA 12. 67-85. o.

Romer, P. (1994) The origins of endogenous growth. - Journal of Economic Perspectives. 8. 3-22. o.

Rostow, W.W. (1960) The stages of economic growth. A non-communist manifesto. Harvard University Press, Cambridge MA.

Schumpeter J.A. (1980) A gazdasági fejlödés elmélete. Vizsgálódás a vállalkozói profitról, a tökéröl, a hitelröl, a kamatról és a konjunktúraciklusról. KJK, Budapest.

Scott, A.J. (1988) New industrial spaces. Pion, London.

Slater, D. (1975) The poverty of modern geographical inquiry, - Pacific Viewpoint 16. 159-176. o.

Smith, N. (1984) Uneven development. Basil Blackwell, Oxford, New York.

Stewart, J.A. (1948) Demographic gravitation: Evidence and application. - Sociometry. 11. 31-58. o.

Storper, M.-Walker, R.A. (1989) The capitalist imperative: territory, technology and industrial growth. Blackwell, Oxford.

Vági G. (1982) Versengés a fejlesztési forrásokért. KJK, Budapest.

Wallerstein, I. (1974) The modern world system. Academic Press, New York, London. 


\section{CONVERGENCE OR DIVERENCE: THE SPATIAL PROCESSES OF TRANSITION FROM POINT OF VIEW OF A GEOGRAPHER}

\section{GÁBOR NAGY}

The paper revised an acut problem of the transition period in Hungary, the result of the spatial processes, the major face of the newly formed regional structure. Using some threories of uneven regional development, the author's hypothesis was a constantly diverging spatial structure with hard, but after 2000 , stabilising, moderate emerging inequalities. To point out the real achievement of Hungarian NUTS 3 level territorial units, he use the GDP/capita index in PPS, comparing to the EU15 average, to see the level of convergence in the 1994-2004 period. This index mirroring - more or less - directly the development of economy. On the other side, to see the social effects of the transition, the author made a calculation - improving some previous methods - to measure the regional differences of HDI (Human Development Index). This complex index compressed 14 variables showed quite similar process between 1990 and 2004, as we could see examining the economy, slow, but constant divergency among NUTS 3 units. The groups of winner and loser areas are quite stable, and movement between the two major categories seems unbelievable. To understand the background of the Hungarian processes in the period of transition, the author used some theories to make clear the role of capital in emerging social-economic spatial inequalities. 